\title{
Female political media discourse in American and English linguocultures: speech strategies and tactics
}

\author{
Elena B. Ponomarenko - Natalia N. Vasilkova - Nadezda N. Volskaya - \\ Larisa T. Kasperova - Anastasia V. Nikolaeva
}

DOI: $10.18355 / X L .2018 .11 .02 .50$

\begin{abstract}
The article is devoted to realization of speech strategies and tactics, description of the gender approach to the study of political media communication, consideration of gender analysis of American and English political texts. Gender strategies are identified as a factor in the realization of the policy language. Strategies and tactics used by female politicians in the political discourse are identified and described. Female strategies and tactics in the American and English political media discourse are established. The gender approach to the study of the characteristic features of political communication presupposes an analysis of the speech interaction of men and women engaged in a political media activity, in accordance with their biological affiliation within the framework of this discourse. Gender analysis of American and English political texts reveals the characteristics of the feminine political media language in American and English linguocultures.
\end{abstract}

Key words: mass media, media discourse, female political media discourse, pragmatic effects, influence, speech strategies and tactics, American and English linguocultures

\section{Introduction}

At the present stage of human development, political discourse is becoming a subject of study of both profile and interdisciplinary research. We believe that such an interest is currently justified. The sphere of politics as one of the spheres of social life is very popular all over the world. Politics, activities, rights, and freedoms in this sphere affect to some extent any representative of the human community. Each of us is connected with this concept.

One of the ways to implement a political dialogue is the speech acts performed by its participants. Its characteristic features have long attracted the attention of many scientists. Despite the fact that the expression "political language" is a generally accepted and most commonly used term, it seems to us that another term must be used to analyze and highlight the features of the speech communication of politicians, namely, the language a politician, its characteristics depending on the biological sex.

The language of the politician is presented by the special language means intended for politicians, deputies, leaders of socio-political movements and associations. This language is necessary in order to quickly establish contact with the target female or male audience (often it is mixed). The language of the politician as an instrument for influencing specific biological groups also fulfills the invitingly and incentive function. At the same time, the language devices and techniques used depend on the target audience, who is divided according to socio-economic and demographic factors, social status and professional characteristics. Today, social, economic, and demographic factors are becoming very important. Depending on those who prevail in the audience, the political leader builds his speech, i.e. the language of the politian is conditioned by gender methods, the forms of presentation and interpretation of the proposed information, by which one can understand the planned impact functions of one or another audience. Male or female audience, in turn, can influence the speech portrait of the politician, the features of the creation and presentation of his speech,

XLinguae, Volume 11, Issue 2, April 2018, ISSN 1337-8384, eISSN 2453-711X 
the ways of presenting and interpreting the information offered. In other words, the gender tactics are biologically coloured linguistic devices and techniques used for the implementation of gender strategies. Gender tactics are primarily aimed at achieving certain objectives of the politician.

The goal of the study is to determine the female features of the implementation of speech strategies and tactics in the American and English political media discourse.

This goal is achieved through the solution of certain tasks: to identify and to describe the strategies and tactics used by female politicians in the American and English political media discourse based on gender approach.

The identification of speech strategies and tactics of American and English female politicians in modern mass media determine the novelty of the study.

\section{Theoretical Research Base: Condition of Problem's Study}

Works of the Russian and foreign scientists (Tarde, 1969; Levinson, 1983; Thompson, 1995; Jamieson, Campbell, 1997; Vodak, 1997; Veretenkina, 2001; Dijk, 2002; Olyanich, 2007; Issers, 2008; Vol'skaya, 2008; Malysheva, 2009; Apresjan, 2013; Ponomarenko, 2013; Rixon, 2014; Strauss, 2014; Voutilainen et al., 2014; Davydyuk, Panasenko, 2016; Nikolaeva, 2013; Nikolaeva, 2016; Kasperova et al., 2016; Zheltukhina et al., 2016, 2017a, 2017b; Aleshchanova et al., 2017; Bobyreva et al., 2017; Vasil'kova, Klushina, 2017; Vasil'kova, 2018; Gulinov et al., 2018; Kasperova, 2018; Vasilkova, 2018) act as theoretical base of our research. Linguistic pragmatics considers discourse as a specific scheme of speech interaction, consisting of certain structural units, active work of participants of communication, expressed in the exchange of information received, presented in emotional and figurative form, in establishing and maintaining contact with each other, choosing means and methods for achieving a definite result in communication (Karasik, 2016).

Political discourse is a specific structural system of the language, characterized by special directions, concepts, and terms, an invitingly and incentive appointment. Many researchers (Levinson, 1983; Thompson, 1995; Zheltukhina, 2003; Issers, 2008; Apresjan, 2013; Karasik, 2016.) agree that the persuasive function of language is most often used in speech political acts. P.B. Parshin (1987) notes that any text has a certain effect on the consciousness of the person to whom it is addressed. If we are talking about a political text, then its main goal is to influence the audience that determines the whole set of methods and techniques that politicians use in their activities (Parshin, 1987). We support the opinion of P.B. Parshin (1987), because it is with the help of a speech that the politician persuades the audience, expresses his opinion and his point of view on certain historical events and phenomena, calling to support him on this issue.

P.B. Parshin (1987) also focuses on the fact that studying the political discourse. It is necessary to focus on the characteristics of two provisions: language as a system and language as a document, letter, inscription (Parshin, 1987). If we consider political discourse as a system, we can see that the language of political texts is not always similar to the common language inherent in an average member of society. Moreover, its peculiarity lies in the fact that ordinary words are often interpreted differently from what meanings we are accustomed to, always understandable and familiar situations are explained somewhat in an unusual and extraordinary way. Often such interpretations of familiar words and situations lead people to confusion and delusion. Something that is unclear, most often is not fun. The second characteristic (discourse as the text of politicians) is connected with the first: namely, there is a different interpretation, interpretation of the text, which differs from the one to which ordinary people are accustomed in their everyday life. It is often believed (among the inhabitants) that this most unusual meaning is genuine. As a rule, it is considered that any political text is to be read with the subtext that explains the meaning and 
interpretation of each word. The semantic load of the word changes, thereby the content of the entire text changes.

Political media speech interaction consists of a certain set of verbal and non-verbal techniques, most often observed in speeches, appeals, politicians' statements and in disputes-discussions with opponents for solving the tasks of communicative interaction in mass media. They are carried out according to certain rules, tested by many years of experience in the struggle for power. Speech is a powerful tool. With its help, participants in communication achieve their goals. The analysis of ways and methods of speech influence is one of not only promising but also complex areas of linguistic research. The complexity of the study is obviously connected with the fact that there are a very large number of them (Formanovskaya, 2008). According to E.M. Vereshchagin (1991), there are differences between individual and group tactics of speech communication. Purposeful planning of political speech presupposes choosing a certain set of communicative strategies and tactics implementing them.

Today, the problem of gender specific features of communication in the political sphere has not been sufficiently studied. In our opinion, this issue is very relevant and important. We believe that it is in the political sphere of society that gender differences are most vividly expressed. There is a huge concentration of political power and the concentration of socio-political relations in this sphere.

The term "gender" is a general term used to characterize certain rules of social behavior, performed by people in accordance with their biological sex and physiological characteristics. The peculiarities of the use of this concept in the sociohumanitarian processes of linguistic activity are visible in this formulation (Zherebkina, 2001).

The study of socio-political relations connected with women's participation in the political process has become the most relevant in Western Europe at the end of the previous century. A comparative analysis of the activities of women engaged in politics in modern conditions has shown that there are significant changes in this phenomenon. Most likely, this is due to the impact of historical events in society in general and the women's movement in particular.

Biological gender identity at the end of the XX century was seen as one of the variables that influenced political behaviour and political communication. Women's participation in the political sphere of society had not been a particular focus of research. For the first time, this question was raised by M. Duverger (1955), who, having conducted a comparative analysis of the quantitative participation of women and men engaged in political activities, noted that women do not show such activity as men. He explained this by the psychological features of the biological sex (Duverger, 1955). At that time, it was believed that as keepers of the hearth women had conservative views. The conclusion was unquestionably made about the biological relationship between belonging to the biological sex with consequent physiological characteristics and behavior. Indeed, based on this characteristic, women, in their physiological and biological characteristics, cannot accept male traits of political communication, and as a consequence - do not have individual political preferences. Thus, the choice of a man was explained by mathematical accuracy, and the choice of a woman was caused by sensory and emotional reasons. Women in principle were considered more psycho-emotional and less politically interested (Duverger, 1955).

The last quarter of the XX century, we can present as a year of growing interest in the problem of the relationship between the biological sex and political participation. Under the influence of the growing female movement and the expansion of women's socio-economic rights and opportunities to participate in the economic sphere, their appearance in leadership positions in the administration was a clear indication of the quantitative growth of women interested in political activities. The emphasis of the linguistic, cultural, and sociological studies began to shift to the issues and addressing

XLinguae, Volume 11, Issue 2, April 2018, ISSN 1337-8384, eISSN 2453-711X 
various social problems, in varying degrees, associated with policy issues. At this time, there have been dramatic changes in female political behaviour. It is characterized by rethinking and reassessment of many issues of a social nature. Personal life with its difficulties and achievements, revision of existing social norms, rules, and requirements are the subject of lively public debate. Previously banned issues and topics are becoming one of the key issues for political dialogue.

At present, the proportional number of men and women in politics has not changed, there are still much more men. At the same time, female politicians have increasingly begun to apply the tactics of aggressive behavior toward his opponent, and at the same time, they often use their gender to gain votes. At the end of the last century, a conditional explanation of the causes and conditions of women's low participation in political life issues and problems, which, according to many scholars, is still considered relevant today, is observed (Genovese, 1992). The most significant factors of political participation include political socialization, biographical characteristics and social features.

Depending on political socialization, men and women play different political roles; have different attitudes towards political participation and active, targeted and informed activities in general. The sphere of political relations (including state and municipal service, administrative activities, etc.) is generally considered not always a good option for the use of female labor, based on its biological and physiological characteristics. In the process of the formation of personality, the brave actions of the boys that guide and direct them to achieve the objectives of the activities, the activities of girls whose main goal is caring about the people that surround them are strongly emphasized and supported (Renzetti, Curran, 1992). These forms of behavior of boys and girls were common in traditional society and in some families that still exist today. This was explained, first of all, by the biological component.

The main aim of participation of male politicians in political activities is the achievement and the realization of goals. In this area, as well as the family, he uses a variety of methods and forms, the possibility of achieving this goal, taking of the external task of the system as a result. Women rarely aim for career growth, they specialize on the psycho-emotional side to achieve the goal, on the solution of internal problems, provided the union and connection of all participants of political media interaction.

Many scientists (Renzetti, Curran, 1992; Genovese, 1992; Voronina, 2001; Burrell, 2006; Atkeson, Carrillo, 2007; Ondercin,Bernstein, 2007; Cortes-Conde, Boxer, 2010; Polyakova, 2011) have identified disparities in the distribution of opportunities used by men and women (because of their biological characteristics) in political media activities. Women and men may differ in the level of education and professional qualifications, income, experience and specialization of work. These factors lead to the fact that women politicians are less represented in the social strata from which they are recruited into the political sphere, so their opportunity for active political activity is much less than that of men politicians. Women often start their political careers from the social sphere or from the experience of social work. As a rule, they have little political experience. Now the situation is changing. There is a large number of women, who received a legal and economic education. There is a quantitative growth of women businesspersons and women lawyers, who actively realize themselves in the sphere of politics (Renzetti Curran, 1992).

Situational factors directly depend on the socialization of women in the family and modern society. For a long time, a woman has been considered the keeper of the hearth. Until now, the majority of women are responsible for the condition of the house, for organizing the family budget, for the development, education, and upbringing, and often the content, for children. These conditions of patriarchal relations have caused women simply to physically not have enough basic time and activity to realize themselves in political activity. This factor determines the point that 
women politicians start their careers much later than men politicians do. Among female politicians or women in high-ranking government positions, very many have an unsettled personal life. This does not mean that male politicians do not experience the state of the choice between class politics and family, in spite of the conflict continue to engage in political activity in all its manifestations, and women because of this conflict, often abandon their political career and various forms of political activity. In addition, women legislators achieve fewer political goals than men politicians do. Most likely, this is due again to the choice: family or career (Renzetti Curran, 1992).

No matter how they minimize the role of women in politics, it is important for their society to work in this direction. Using social experience, we can say that in the first place women often have social policy issues (education, health care, ecology, care and guardianship, support for socially unprotected categories of people) that are on the periphery of men's interests.

\section{Methodological Bases and Research Methods}

The gender approach to the study of political communication takes a special place. According to the pragmatic analysis, the implementation of speech strategies and tactics in the American and English female political media discourse is carried out through the interaction of verbal and non-verbal components.

The material for analysis was the media texts of speeches delivered by American and English female political figures published on the Internet (42 media texts of speeches of $\mathrm{H}$. Clinton, M. Albright, M. Thatcher, M. Theresa, etc.).

Investigating the gender features of political interaction, we pay attention to the gender specificity of communication in general. O.A. Voronina (2001) singles out the following characteristic features of communication between men and women in the process of political interaction:

1. Female politicians are more mobile and changeable in their political speech and actions; they can easily change the social role in the process of speech interaction: they can put themselves in the place of the listener, listen to another point of view. They pay attention to the comments. It is much more difficult for men to switch. They often show emotional detachment. When discussing the topic of political dialogue, they pay little attention to the remarks that are not connected with it, do not pay attention to the comments and questions of the audience.

2. As evidence, women are more likely to give specific factual examples, based on their own experience or citing the experience of their friends or relatives. The male politicians do not do that. It is much easier for them to plan for the future than to take into account and analyze the mistakes of the past.

3. A contradictory picture has developed in the analysis of interrupting the interlocutor during the conversation. O.A. Voronina (2001) focuses on the diversity of political dialogue. Very often, the initiative of interrupting comes from men participating in this dialogue. This phenomenon is harmful to the process of communication.

4. In the speech of male politicians, there is also a pronounced specificity, accuracy, categorical judgments and proposals, the lack of emotional coloring of political texts, meaningful rudeness of speech acts. Very often, in social same-sex groups, obscenity is used in the speeches of all participants in the communication process. If the social group is mixed, this feature is not observed.

5. One of the features of women's political speech is the emotional exaggeration of the examples, facts, and phenomena used.

6. Male politicians often make associative connections with such certain directions of human activity as men's hobbies or professionalism (for men); female politicians emphasize the nature, animals surrounding the ordinary world.

XLinguae, Volume 11, Issue 2, April 2018, ISSN 1337-8384, eISSN 2453-711X 
7. In the female speech, there is a very large proportion of the psycho-emotional coloring of their statements; men do not often use any assessment in their statements. Women often focus the audience's attention on the positive assessment (in extremely rare cases - neutral). Men engaged in political activity, focus the audience's attention on a negative assessment of (sometimes rather rude).

These features of speech of women and men participating in political dialogue are defined as the main directions. The peculiarities of speech can also include the features of psychological character, temperament, professional activity, the role played by the politician (outside of biological affiliation) in society as a whole, and the socio-status group in particular.

Foreign scientists dealing with the problems of communication of women legislators have established the characteristic features of this behavior:

- diminutive suffixes are very often used in the speech acts;

- the predominance of indirect speech acts; the words "please", "thank you", "would you be so kind" are used more often in women's speech. Sometimes they sound in the form of questions.

- lack of dominance, ability to listen to the participants of the dialogue and pay attention to their problems.

By giving a general assessment to speech acts of women legislators, we can talk about them as human, addressed to human problems. This distinctive feature of political women's dialogue has a negative influence on the participants in this communication process. Such soft, gentle, human communication forms the opinion that women are weaker, more insecure and generally less competent in solving political issues (Genovese, 1992).

Thus, the" human" approach to language, adopted in linguistics, focuses on all the characteristics of a person as a person and as a professional, reflected in the language. Therefore, gender is understood as a social phenomenon, viewed through the prism of cultural characteristics.

\section{Results and Discussion}

We will identify gender strategies as a factor in the realization of the language of the politician in mass media, identify and describe the speech strategies and tactics used by female politicians in the American and English political media discourse.

Having analyzed the speeches, namely speeches, appeals, and publications, politicians (both men and women) we can focus on the characteristics of the two pronounced gender strategies due to biological characteristics:

1. The use of characteristic features (male or female) to determine the characteristics of a speech portrait. The gender strategy applied in the political dialogue uses certain tactics: radical change and correction of their verbal behavior;

2. Appeal either to the female or male target audience. It highlights the gender tactic of speech "contemplation" and the gender tactic of using stereotypes and metaphors, primarily to enhance the emotional expressiveness of speech.

The categorical wording is very clearly traced, an orderly tone is used. Such stylistic devices form a certain effect of the impending danger. The quote below consists of simple sentences. Moreover, this seeming simplicity has a very great semantic meaning: rapid reporting of this message (namely, its content aspect) to the recipients, i.e. to the audience.

"The United States and Europe must stand up to this kind of behavior, and to all who champion it. For our sake - and for the sake of Russia's people, who deserve a better relationship with the rest of the world - the United States and Europe must not allow Russia's aggression to achieve any benefit. Not in Georgia - not anywhere" (Rice, 2008).

The speech was devoted to the forthcoming trip to Asia. She speaks and builds her speech as a male politician. Initially, she clearly formulates the goal of the trip, then 
very clearly, logically, with mathematical precision, consistently, point by point outlines why she does it. The speech by K. Rice (2008) demonstrates the complete absence of characteristic features for women's political discussion. The appeal to the audience draws attention to its logical completeness and validity, which is inherent in the masculine political discourse. This is an example of a radical change in the verbal behavior of a female politician for the realization of the tasks set.

The tasks of a communicative political strategy can be achieved by using other speech methods and techniques as in speeches of M. Albright (2016).

"I know Hillary Clinton will be that president. Because I have known her for more than 25 years. Because I have seen her fight and win for our country and for causes that count. When Hillary it. Was First Lady we went to the Beijing women's conference and she courageously. Stood out and spoke out. On behalf of human rights and women's rights inspiring millions. To fight for a better future. We went super. Where I showed her the city of my birth. And made her eat checked cabbage. She didn't like it very much. We met me at bats. Whom she'd like very much because he made so many means of freedom who come true. When Hillary served in the senate. I saw her work day and night as a member of the armed services committee. Working with Republicans and Democrats to keep our military strong. And protect our troops and their families. And when Hillary served as secretary of state. I watched her partner with President Obama to restore our country's reputation. Around the world. She thought terrorism. She stopped the spread of nuclear weapons. And she promoted diplomacy. Deaf bands. Development and democracy Smart power. In every corner of the world. As I travel. Around the world today I'm reminded how important it is that the person who represents our nation is thrusted. By our allies and who listens more than she talks. Marion I share may have few things in common. We both went to Wellesley legs. I know where sea otters steady habits. We are both mothers and grandmothers so lined an oh wait she got her management skills. We are both very proud of our daughters and grandsons witnessing done something right. But we also know what it's like to step up that plane with the words United States of America on it. She knows that's safeguarding freedom and security is not like hosting a TEU reality show" (Albright, 2016).

M. Albright, a former State US Secretary, in her speeches has used the term "family" many times. The issue of intergenerational relations is raised, attention is focused on the formation of a sense of respect for the older generation, which contributes to the creation of a vivid image of the mother and wife.

American and English political leaders are characterized by a desire to use a wellstructured and well-formulated speech. Thus from the analyzed political texts (speeches, appeals, statements) of bright political leaders of Europe and America ( $\mathrm{H}$. Clinton, M. Albright, C. Rice, M. Thatcher, M. Therese) a large number of women legislators chose gender strategy, that differed in the use of changing acts of speech influence. It is remarkable that the emphasis on the use of the characteristic features of women's strategies in the above-mentioned political leaders is not observed (this cannot be observed either in the analysis of public texts or by conducting a comparative characteristic of the audience).

Thus, accuracy and correctness, the need for competent selection of means and methods of political communication contributes to the creation of bright and emotional speech. In this case, any speech is remembered, thus influencing the effectiveness of the impact on the public.

American and English female politicians, carrying out their professional and public activities in their speeches. H. Clinton (this is her peculiarity) prefer a balanced (or consistent) version of the use of gender strategies. It allows them to adjust their speech or appeal, a statement if necessary, taking into account and sharing the interests of the audience present on a biological basis.

XLinguae, Volume 11, Issue 2, April 2018, ISSN 1337-8384, eISSN 2453-711X 
For analysis, we took excerpts of speeches, appeals by H. Clinton, M. Albright, M. Thatcher and other female politicians. The pragmatic analysis shows that for female politicians the strategies of positioning and self-representation prevailed. However, female politicians more often use the tactics of identification with voters. For example, $\mathrm{H}$. Clinton often resorts to it.

"Over the last three days, you've seen some of the people who've inspired me. People who let me into their lives, and became a part of mine. People like Ryan Moore and Lauren Manning. They told their stories Tuesday night. I first met Ryan as a sevenyear old. He was wearing a full body brace that must have weighed forty pounds. Children like Ryan kept me going when our plan for universal health care failed ... and kept me working with leaders of both parties to help create the Children's Health Insurance Program that covers 8 million kids every year" (Clinton, 2016).

This excerpt shows that $\mathrm{H}$. Clinton, occupying a special social position, wants to show that her family is no different from other American families. Thus, she brings herself and her husband closer to common American people. Here we also see the specific features of women politicians. H. Clinton appeals to such concepts as family, to raise a child.

In 2008, H. Clinton often used identification tactics, for example:

"We are Americans. We're not big on quitting" (Clinton, 2008).

Here the female politician associates herself with the American people and at the same time expresses her pride in the fact that she is an American. This is a good move, because the American nation is characterized by deep patriotism and takes its national identity very seriously.

Another female politician, M. Albright, also resorted to the tactics of identification during her speeches:

"Mr. President, and Madam First Lady - dear Michelle - distinguished guests" (Albright, 2010).

"President Monaco, distinguished faculty and trustees, honored guests, most important people, members of the Class of 2015, families and friends: good morning" (Albright, 2015).

In this passage, Albright uses such addresses as dear Michelle, distinguished guests, distinguished faculty and trustees, honored guests, most important people, members of the Class of 2015, families and friends that make the speaker closer to the audience and create a friendly atmosphere. Therefore, it will be easier for the politician to convey his or her thoughts and influence the minds of those present.

In the following example, M. Albright associates herself with all people using the pronouns we, our:

"No matter our race, creed, gender, or sexual orientation, we are all equal shareholders in the American Dream. And that means we do not fear our differences, we embrace them" (Albright, 2016).

Female politicians have used other tactics that belong to the strategy of selfpresentation, for example, the use of metaphorical models. Metaphor helps to attract the attention of the listener and make the speech of the politician more interesting.

Women in their speeches resort to less aggressive images, for example:

"Spring is the season of hope and renewal, of planting the seeds for new crops, and my hope is that both in Iran and the United States we can plant the seeds now for a new and better relationship in years to come" (Albright, 2000).

Here, M. Albright used the metaphor of spring to show that both new crops sprout at this time of year, and relations between Iran and the United States can begin from scratch. Thus, the politician calls not to look back, remembering old conflicts, and to look only forward and to meet new opportunities.

Unlike other female politicians, Margaret Thatcher in her speeches used metaphors that are more aggressive. This can be explained by the fact that Thatcher adhered to 
the male style of behavior in her political activities. No wonder, her nickname was "Iron Lady".

"In view of what happened under the Single European Act when we got our fingers burned, it surely is time to heed Kipling's warning: "And the burned Fool's bandaged finger goes wabbling back to the Fire". Do not let ours be that bandaged finger" (Thatcher, 1993).

In her speeches, Margaret Thatcher also used metaphors related to the seasons.

"We are coming slowly, painfully to an autumn of understanding. I hope it will be followed by a winter of common sense" (Thatcher, 1980).

Female politicians in their speeches, as well as male politicians, appeal to such fundamental concepts as democracy, law, unity, freedom, liberty, homeland, security, safety, future, strength, growth, faith, prosperity etc., for example:

"I believe that our economy isn't working the way it should because our democracy isn't working the way it should. That's why we need to appoint Supreme Court justices who will get money out of politics and expand voting rights, not restrict them. And we'll pass a constitutional amendment to overturn Citizens United! I believe American corporations that have gotten so much from our country should be just as patriotic in return" (Clinton, 2016).

The concepts female such as family, children, home, etc., a politician uses more often in her speeches than a male politician, for example:

"Because it's not just a detail if it's your kid - if it's your family. $<\ldots>$ Building a better tomorrow for our beloved children and our beloved country." (Clinton, 2016)

In this example, $\mathrm{H}$. Clinton acts as an ordinary woman who cares for her loved ones. In addition, this is one of the strongest means of manipulating consciousness, as the image of the woman-guardian of the hearth always impressed ordinary people. In her election campaign, H. Clinton often appeals to this image:

"Standing here as my mother's daughter, and my daughter's mother, I'm so happy this day has come" (Clinton, 2016).

Here, the politician emphasizes that she, like many other mothers, is concerned about the future of her daughter.

Female politicians seldom use the promise tactic as part of the self-presentation strategy. This can be explained by the fact that women seldom propose their candidacy for any political post, and manipulative strategies and tactics especially the tactics of the promise are most often used during the election campaigns.

H. Clinton used in her speeches special images that meet the national specifics of the American people. For example, implementation of the "American Dream", emancipation, fight against racism, etc.

"We're going to give small businesses a boost. Make it easier to get credit. Way too many dreams die in the parking lots of banks. In America, if you can dream it, you should be able to build it. We're going to help you balance family and work. And you know what, if fighting for affordable child care and paid family leave is playing the "woman card," then Deal Me In!" (Clinton, 2016).

In this fragment of the speech, $\mathrm{H}$. Clinton promises to fight for civil rights, for the rights of workers, etc.

As Americans always pay attention to the equality of all strata of the population, the use of the above concepts in the context of the struggle for them will allow the candidate to obtain the recognition of the majority of citizens.

Within the framework of cooperation strategies, women politicians, like men, use an argumentative strategy. Thus, in the following example M. Albright draws an analogy between the struggle for women's rights and such significant historical phenomena as the abolition of slavery, the end of the policy of apartheid, the guarantee of civil rights and freedoms. Thus, the politician emphasizes the indispensability and inevitability of the reforms proposed by her.

XLinguae, Volume 11, Issue 2, April 2018, ISSN 1337-8384, eISSN 2453-711X 
"We have to decide whether we all will work together so we all can rise together." (Clinton, 2016).

Claiming that poverty must and can be fought, the female politician proves that there is nothing supernatural in this, it is in the power of people:

The study showed that conflict strategies are less represented in the speeches of female politicians than male. Nevertheless, H. Clinton in her pre-election speeches also used the tactics of opposition, which relate to conflict strategies, for example:

"John McCain says the economy is fundamentally sound. John McCain doesn't think that 47 million people without health insurance is a crisis. John McCain wants to privatize Social Security. And in 2008, he still thinks it's okay when women don't earn equal pay for equal work" (Clinton, 2008).

Here Clinton acknowledges the errors of judgment of another candidate for the presidency on the situation in the country.

In 2016, Hillary Clinton once again activated her campaign, fighting for the presidency with a candidate from the Republican Party by D. Trump. Clinton was proposed as candidate for the presidency from the Democratic Party. At the closing of the Congress of the Democratic Party in her speech, in contrast to D. Trump, she thanked her family (that is a distinctive feature of the political communication of female politicians), thereby indicating a commitment to the values, honoring of which is necessary for politicians in the United States.

The election campaign of Hillary Clinton (based on an analysis of her pre-election speeches, appeals, debates on television) is mainly aimed at women.

In her political debates, she constantly touches upon purely "female" issues and concerns. She calls for the real realization of the political rights of men and women rather than the declared equation, develops the theme of "freedom":

"The most enduring values. Freedom and equality, justice and opportunity" (Clinton, 2016).

With this phrase, she emphasizes the necessity and importance of women's rights and freedoms. In this way, it attracted the attention of the female half of its electoral campaign.

The political speech of American female politicians is often saturated with quotations, allusions, aphorisms and other elements to make it more expressive, bright, memorable, and emotional. Using other people's quotes or aphoristic units in the political dialogue, politicians either accept the point of view set forth in it, or disagree with it. Everything depends on their ideological attitudes and values. If political discourse is addressed to a wide audience, so we consider social, moral norms and rules of social life adopted in a certain, historically conditioned, national community. Political means of communication are a powerful resource of power through which state and social and public institutions implement their policies, propose and promote certain images of reality, present social actors in the political space of the world as a whole, and the individual state or country in particular. A distinctive feature of the policy is that many political actions by their nature are speech acts, forms or ways of submitting and interpreting the necessary information. No political regime can exist without political communication.

\section{Conclusion}

The gender approach to the study of the characteristic features of political communication presupposes an analysis of the speech interaction of men and women engaged in a political activity, in accordance with their biological affiliation within the framework of this discourse. Gender analysis of American and English political texts reveals the characteristics of the feminine political language in both linguocultures.

Having carried out the linguopragmatic analysis of practical material in the gender aspect, we have found out that the strategies of conflict and discredit are less 
characteristic of female politicians. Aggression is by nature not characteristic of women, so politicians, who belong to this sex, use other ways to attract the audience to their candidacy. Nevertheless, in crisis political media communication, during election process we fix examples of verbal aggression on the part of women politicians.

The prevailing strategy for female politicians is the strategy of self-presentation. The most used tactics are tactics of identification and use of metaphorical models.

Unlike male politicians, women appealed to such concepts as family, children, which created a positive image for them. Thus, women politicians enlisted the support of the female half of the audience and couples.

Female politicians rarely use tactics of promise and opposition. We believe that these tactics are used mainly during the election campaigns, and women, based on their own observations, rarely propose themselves as a candidate for a political post or participate in these campaigns.

\section{Bibliographic references}

ALBRIGHT, M. 2000. Remarks by Secretary of State Madeleine K. Albright. On American-Iranian Relations. 17.03.2000. Available online: http://www.parstimes.com/histor-y/albright_speech.html

ALBRIGHT, M. 2015. Madeleine Albright gave this commencement speech at Tufts University. 18.05.2015. Available online: http://time.com/collectionpost/3882439/madeleine-albright-tufts-graduation-speech/

ALBRIGHT, M. 2010. Madeleine Albright. White House Address Commemorating International Women's Day. 08.03.2010. Available online: http://www.americanrhetoric.com/spe-

eches/madeleinealbrightinternationalwomensdayspeech.htm

ALBRIGHT, M. 2016. Madeleine Albright's Speech at the Democratic National Convention. 26.07.2016. Available online: http://abcnews.go.com/Politics/video/madeleine-albrights-speech-democraticnational-convention-40909509

ALESHCHANOVA, I.V. - FROLOVA, N.A. - MOROZOVA, E.V. ZHELTUKHINA, M.R. 2017. Psychological and Acmeological Aspect of Educational Cognitive Competence Development. In: Advances in Social Science, Education and Humanities Research (ASSEHR), vol. 97, pp. 19-24. ISSN: 23525398.

APRESJAN, V. 2013. Corpus Methods in Pragmatics: The Case of English and Russian Emotions. In: Intercultural Pragmatics, vol. 10 (4) , pp. 533-568. ISSN $1612-$ 295X.

ATKESON, L.R. - CARRILLO, N. 2007. More is Better: the Influence of Collective Female Descriptive Representation on External Efficacy. In: Politics and Gender, vol. 3, n. 1, pp. 79-101. ISSN 1743-923X

BOBYREVA, E.V. - DMITRIEVA, O.A. - ZHELTUKHINA, M.R. - BUSYGINA, M.V. 2017. Principle "Understanding" from Perspective of Linguistic Investigations 2017. In: Advances in Social Science, Education and Humanities Research (ASSEHR), vol. 97, pp. 52-56. ISSN: 2352-5398.

BURRELL, B. 2006. Looking for Gender in Women's Campaigns for National Office In 2004 And Beyond: In What Ways is Gender Still a Factor? In. Politics and Gender, vol. 2, n. 3, pp. 354-362. ISSN 1743-923X

CLINTON, H. 2008. US Election: Full text of Hillary Clinton's speech in Denver 27.08.2008. Available online: https://www.theguardian.com/world/2008/aug/27/uselection-s2008.hillaryclinton 
CLINTON, H. 2016. Transcript: Hillary Clinton's Speech at the Democratic Convention. 28.07.2016. Available online: https://www.nytimes.com/2016/07/29/us/politics/hi-llary-clinton-dnc-transcript.html CORTES-CONDE, F. - BOXER, D. 2010. Humorous Self Disclosures as Resistance to Socially Imposed Gender Roles. In: Gender and Language, vol. 4, n. 1, pp. 73-97. ISSN 1747-6321.

DAVYDYUK, Y. - PANASENKO, N. 2016. Figuring the Male and Female: Fire and Water in Bradbury's (science) Fiction. In: The Journal of University of SS Cyril and Methodius in Trnava. Warsaw: De Gruyter Open, vol. 1, pp. 4-74. ISSN 2453-8035.

DIJK, T.A. 2002. Political Discourse and Ideology. Paper contributed to Jornadas sobre el Discurso Político. Barcelona: Institut Universitari de Lingüística Aplicada. ISBN: 84-477-0800-4.

DUVERGER, M. 1955. The Political Role of Women. Paris: UNESCO.

FORMANOVSKAYA, N.I. 2008. Russkij rechevoj ehtiket: Lingvisticheskij i metodicheskij aspekty. Moscow: Izdatel'stvo LKI. ISBN: 978-5-382-00752-6

GENOVESE, M. 1992. Women as National Leaders. Newbury Park: Sage. ISBN 0803943385

GULINOV, D.Y. - ZHELTUKHINA, M.R. - SHESTAK, L.A. - SLYSHKIN, G.G. KATERMINA, V.V. - CHERVYAKOVA, L.D. 2018. Modern Language Policy: Specifics of Formation and Development of the French Vertical. In: Modern Journal of Language Teaching Methods, vol. 8, n. 2, pp. 159-173. ISSN: 2251-6204

ISSERS, O.S. 2008. Kommunikativnyje strategii I taktiki russkoj rechi. Moscow: Editorial URSS. ISBN 978-5-382-00698-7.

JAMIESON, K.H. - CAMPBELL, K.K. 1997. The Interplay of Influence: News, Advertising, Politics and Mass Media. Belmont: Wadsworth Publishing Company. ISBN 9780534533649.

KARASIK, V.I. 2016. Diskursivnoe proyavlenie lichnosti. In: Vestnik Rossijskogo universiteta druzhby narodov, n. 4, pp. 56-77. ISSN 2312-9182.

KASPEROVA, L.T. - KLUSHINA, N.I. - SELEZNYOVA, L.V. - SMIRNOVA, N.V. - TORTUNOVA, I.A. 2016. The Impact of Internet on Genre and Stylistic Features of Media Texts. In: Global Media Journal, n. 3, 17-24. ISSN 1550-7521

KASPEROVA, L.T. 2018. Stilisticheskie i zhanrovye osobennosti internetkommentariev. In: Russkaya rech', n 1, pp. 63-69. ISSN 0131-6117

LEVINSON, S.C. 1983. Pragmatics. Cambridge: Cambridge University Press. ISBN 978-0521294140.

MALYSHEVA, O.P. 2009. Kommunikativnye strategii i taktiki v publichnyh vystupleniyah. In: Izvestiya Rossijskogo gosudarstvennogo pedagogicheskogo universiteta im. A.I. Gercena, vol. 96, pp. 206-209. ISSN: 1992-6464.

NIKOLAEVA, A.V. 2013. Sovremennyj zhurnalistskij tekst: neizbezhnaya transformaciya. In: Russkaya rech', № 6, pp. 62-65.

NIKOLAEVA, A.V. 2016. Internet-tekst kak novyj vid kommunikacii. In: Russkaya rech', n 3, pp . 46-50. ISSN 0131-6117

OLYANICH, A.V. 2007. Prezentatsionnaya teoriya diskursa. Moscow: Gnosis. ISBN 5-7333-0184-8.

ONDERCIN, H.L. - BERNSTEIN, J. 2007. Context Matters: the Influence of State and Campaign Factors on the Gender Gap in Senate Elections 1988-2000. In: Politics and Gender, vol. 3, n. 1, pp. 33-53. ISSN 1743-923X

PARSHIN, P.B. 1987. Lingvisticheskie metody v konceptual'noj rekonstrukcii. In: Sistemnye issledovaniya. Moscow: Progress.

POLYAKOVA, L.S. 2011. Gendernye strategii kak faktor realizacii yazyka politika. In: Lingvokul'turologiya, vol. 5, pp. 67-72. ISBN 5-7186-0287-5

PONOMARENKO, E.B. 2013. Linguistic Manipulation Devices. GISAP: Philological Sciences, n. 1, pp. 62-65. ISSN 2053-1532. 
RENZETTI, C.M. - CURRAN, D.J. 1992. Women, Men, and Society. Boston: Allyn \& Bacon. ISBN 9780205265626

RICE, C. 2008. Address at the German Marshall Fund on U.S. - Russian Relations. Available online:

http://www.americanrhetoric.com/speeches/condoleezzariceonrussia.htm

RIXON, P. 2014. Popular Newspaper Discourse: The Case of UK TV Criticism from the 1950s to the 1980s. In: Journal of Historical Pragmatics, vol. 15, n. 2, pp. $314-$ 330. ISSN 1566-5852.

STRAUSS, D. 2014. Ideological Closure in Newspaper Political Language During the U.S. In: Journal of Historical Pragmatics, vol. 15, n. 2, pp. 255-291. ISSN 1566-5852. TARDE, G. 1969. On Communication and Social Influence. Chicago: University of Chicago Press. ISBN 0226789713.

THATCHER, M. 1980. The lady's not for turning. Available online: https://www.thegua-rdian.com/poli--tics/2007/apr/30/conservatives.uk1

THATCHER, M. 1993. House of Commons Speech. URL: https://www.margaretthatcher.org/document/108314

THOMPSON, J. 1995. The Media and Modernity. Cambridge: Polity Press. ISBN: 9780804726795.

VASIL'KOVA, N.N. 2018. Realizaciya agonal'nyh strategij v publichnyh sporah politicheskogo diskursa. Available online: http://www.mediascope.ru/2413 ISSN 2074-8051

VASIL'KOVA, N.N. - KLUSHINA, N.I. 2017. Prepodavanie russkogo yazyka i stilistiki v sisteme mediaobrazovaniya na fakul'tete zhurnalistiki MGU. Didakticheskij aspect. In: Annales Universitatis Paedagogicae Cracoviensis. Studia ad Didacticam Litterarum Polonarum et Linguae Polonae Pertinentia, n. 3, pp. 55-60. ISSN 24505013

VERESHCHAGIN, E.M. 1991. Kommunikativnye taktiki kak pole vzaimodejstviya yazyka i kul'tury. In: Russkij yazyk i sovremennost': problemy i perspektivy rusistiki: Doklady Vsesoyuz. nauch. konf. Moscow, pp. 32-44.

VERETENKINA, L.Y. 2001. Strategii, taktiki i priemy manipulirovaniya. Ekaterinburg: Izd-vo Ural. ISBN 5-7535-0951-3

VODAK, R. 1997. Yazyk. Volgograd: Peremena. ISBN 5-88234-249-X

VOL'SKAYA, N.N. 2008. "Neputevye zametki" dlya neputevykh telezritelej? In: Zhurnalistika i kul'tura russkoj rechi, n. 3, pp. 20-24. ISSN 2222-1492.

VORONINA, O.A. 2001. Teoretiko-metodologicheskie osnovy gendernyh issledovanij. Moscow: MCGI-MVSHSEHN-MFF. ISBN 5-85133-072-4

VOUTILAINEN, L. - HENTTONEN, P. - KAHRI, M. - KIVIOJA, M. - RAVAJA, N. - SAMS, S. - PERAKYLA, A. 2014. Affective Stance, Ambivalence, and Psychophysiological Responses during Conversational Storytelling. In: Journal of Pragmatics, vol. 68, pp. 1-24. ISSN: 0378-2166.

ZHELTUKHINA, M.R. - BIRYUKOVA, E.V. - GERASIMOVA, S.A. - REPINA, E.A. - KLYOSTER, A.M. - KOMLEVA, L.A. 2017a. Modern Media Advertising: Effective Directions of Influence in Business and Political Communication. In: Man in India, vol. 97, n. 14, 207-215. ISSN: 0025-1569.

ZHELTUKHINA, M.R. - MOUZYKANT, V.L. - BARABASH, V.V. PONOMARENKO, E.B. - MOROZOVA, E.V. - MORI, S. 2017b. Russian and Japanese Younger Generations in Search for a New Media Product. In: Man In India, vol. 97, n. 3, pp. 223-236. ISSN: 0025-1569.

ZHELTUKHINA, M.R. - SLYSHKIN, G.G. - PONOMARENKO, E.B. BUSYGINA, M.V. - OMELCHENKO, A.V. 2016. Role of Media Rumors in the Modern Society. In: International Journal of Environmental and Science Education, vol. 11, n. 17, pp. 10581-10589. ISSN 1306-3065.

XLinguae, Volume 11, Issue 2, April 2018, ISSN 1337-8384, eISSN 2453-711X 
ZHELTUKHINA, M.R. 2003. Tropologicheskaya suggestivnost' massmedial'nogo diskursa. Volgograd: IYA RAN. ISBN 5-88234-568-5.

ZHEREBKINA, I.A. 2001. Vvedenie v gendernye issledovaniya. St.Petersburg: Aletejya. ISBN 5-89329-397-5

Words: 7537

Characters: $50118(27,8$ standard pages)

Associate Prof. Elena B. Ponomarenko, PhD. in Philology

Faculty of Philology

Peoples' Frendship University of Russia

10/2 Mikluho-Maclay

117198 Moscow

Russia

ponomar_elena@mail.ru

Associate Prof. Natalia N. Vasilkova, PhD. in Philology

Faculty of Journalism

M.V. Lomonosov Moscow State University

Mokhovaya Street 9/1

125009 Moscow

Russia

n.vasilkova@mail.ru

Associate Prof. Nadezda N. Volskaya, PhD. in Philology

Faculty of Journalism

M.V. Lomonosov Moscow State University

Mokhovaya Street 9/1

125009 Moscow

Russia

navolskaya@yandex.ru

Associate Prof. Larisa T. Kasperova, PhD. in Philology

Faculty of Journalism

M.V. Lomonosov Moscow State University

Mokhovaya Street 9/1

125009 Moscow

Russia

latael@mail.ru

Associate Prof. Anastasia V. Nikolaeva, PhD. in Philology

Faculty of Journalism

M.V. Lomonosov Moscow State University

Mokhovaya Street 9/1

125009 Moscow

Russia

9320078@mail.ru 